\title{
INDUSTRIALIZED HOUSING IN CHINA: A COIN WITH TWO SIDES
}

\author{
Xiaoling ZHANG $1 \bowtie$ and Martin SKITMORE ${ }^{2}$ \\ ${ }^{1}$ Department of Urban Planning and Design, The University of Hong Kong, Pokfulam Road, \\ Hong Kong, P.R. China \\ E-mail: zhangxiaoling1982@gmail.com \\ ${ }^{2}$ Faculty of Built Environment and Engineering, School of Urban Development, Queensland \\ University of Technology, GPO Box 2434, Brisbane, 4001 Queensland, Australia \\ E-mail:rm.skitmore@qut.edu.au
}

Received 4 July 2011; accepted 31 August 2011

\begin{abstract}
China today is experiencing a time when housing is needed more than ever and one approach satisfying this need is by industrialization - a streamlined process aimed at generating profits and promoting energy efficiency in the housing sectors. Although large housing programs have been completed in China, few housing projects have been built in an industrialized manner. One contributing factor is that industrialization is not omnipotent and, just as a coin has two sides, not all the outcomes of industrialization are beneficial. In this paper, a preliminary assessment is made of these two sides - the benefits and hindrances of industrialized housing in China - by literature review and survey. Case studies are used to verify the questionnaire survey results and from which the advantages and disadvantages involved are compared. The findings indicate the need for formulating policies to encourage industrialized housing in China and for well-planned R\&D themes to be implemented simultaneously with industry practices in the near future.
\end{abstract}

KEYWORDS: Industrialized housing; Benefits; Hindrances; Case study; China

\section{INTRODUCTION}

Contemporary China is experiencing a shift from a traditional labour-intensive to modern technological approach in its housing industry in the form of an increased industrialization (commonly called manufacturing or prefabrication housing), as this offers an innovative alternative for many developing countries in response to the urgent demand for rapid and economically viable mass-produced dwellings. Despite its widespread use in academia and industry, researchers have yet to reach a consensus on the definition of 'industrialized housing' (IH). For example, it can be the assembly of houses through factory-produced house components; the application of modern systematized methods of design; production planning and control; as well as mechanized and automated manufacturing processes and a way to simplify the supply chain through a more standardized production process (Gann, 1996; Gibb, 2001; Lessing et al., 2005; Voordijk and Meijboom, 2006). Other variations include considering the industrialization approach in buildings such as in the prefabrication building (Dawood, 1996; Gibb, 2001); modular housing innovations (Halman et al., 2008); industrialized building system (Badir et al., 2002; Richard, 2004) ; supply chain management (London and Kenley, 2001; Naim and Barlow, 2003; Green et al., 2005); lean construction (Gann, 1996; 
Howell and Kostela, 2000); scheduling (Austin et al., 2000; Schmitt and Faaland, 2004); re-engineering (Winch, 2003; Cheng and Tsai, 2003); and standardized process (Kagioglou et al., 2000).

Many benefits have been claimed for IH. Jailor and Poon (2009), for example, note several significant advantages associated with the adoption of prefabrication compared with traditional construction, such as improved quality control, reduction of construction time, construction waste, dust and noise on-site, and labour requirements on-site. Similarly, Badir et al. (2002) also found savings in labour and material costs to be a major benefit, with reduced construction site waste being echoed by Mokhtar and Mahmood (2008), who consider the use of prefabrication to be one of the most effective waste minimization methods possible in the construction industry. Some recent studies (Tam et al., 2007; Tam et al., 2005; Chiang et al., 2006), on the other hand, have identified the hindrances involved, such as high overall cost, lack of standard components, lack of skilled labour and lack of hoist equipment capacity in applying IH generally.

Though the application of IH can offer many benefits, the approach is still new to Chinese housing builders, especially in the construction of high-rise residential buildings. The impact of urbanization now runs deep in many industries in China while the housing industry is still in an extensive development stage. IH has therefore been introduced with a high priority to help survive the challenging housing market ahead. For one thing, a list of IH standards has been promulgated in China, which has provided technical support for IH practices. Secondly, a preliminary IH building materials and standardized production system has been established. In particular, increasing number of large integrated build-operate housing industry groups, such as the Vanke Corporation and Zhejiang Baoye Group, have come into being. Intensive competition and a growing demand for a varied and customer oriented housing are some of the forces that have encouraged house building firms to consider new types of product and process design (Halman et al., 2008). However, only few research institutes and housing developers in China focus on IH, and few buildings have been constructed with these industrialized methods (Liu and Ying, 2009). The reason appears to be that housing developers in China are reluctant to switch technologies, perhaps because of their lack of familiarity and experience of industrialized approaches in buildings. Numerous studies have also investigated the implementation of the IH approach and its potential (e.g. Gibb and Isack, 2003; Goodier and Gibb, 2007; Jailor and Poon, 2009). To date, however, very few studies have been made of the advantages and disadvantages of adopting IH in China, although meanwhile the housing problem grows increasingly acute as the Chinese government struggles to meet rapidly growing housing needs.

This article, therefore, seeks to bridge some of the knowledge gap in the benefits and limitations of $\mathrm{IH}$ approaches in the Chinese house building industry. Specific attention is paid to the historical review of housing industrialization methods. This is followed by a questionnaire survey to investigate the benefits and hindrances of using IH approaches. Several case studies are then described to evaluate and compare the benefits and limitations of IH. Finally, some important implications and useful directions for future research are identified and discussed.

\section{AN OVERVIEW OF HOUSING INDUSTRIALIZATION METHODS}

IH has been used in the European countries during periods of high demand, such as after the World Wars and during the slum clearances of the 1960s. In 1968, more than 1,100,000 IH units were produced in Europe, comprising 
an average of some $40 \%$ of all units built. In fact, it is estimated that $25 \%$ of all European construction in the post-war period was by industrialized building methods (Lin and Stotesbury, 1970). Denmark established modular coordination legislation in the 1960s (Jaillon and Poon, 2009) and, in total, approximately 1 million industrialized homes were built during the 20th century, many of which were designed to be of a temporary nature (Parliamentary Office of Science and Technology, 2003). During the 1960s and 1970s, production-focused and non-customer oriented building systems were developed and used in countries such as Sweden and Great Britain. In the early 1970s, the USA government also adopted several prefabricated building systems. System building is one kind of IH where prefabrication, standardization, and methods for production and quality control are central ingredients (Gann, 1996). However, this mass-production-like approach failed for various reasons, not least of which being lack of customer orientation.

After the mid-1980s and during the 1990s, mass customized IH emerged in Japan, where it has since gradually grown into the substantial industry sector it is today (Barlow et al., 2003). The approach includes an increased customer orientation and improved processes for integrating design, production, information and management, brought about by organisational and technological change and innovation (Barlow and Ozaki, 2005). Targeting more mainstream culture, Japan's version of IKEA is called Muji now offers a line of prefabricated homes as a retroactive spatial organizer of their extensive minimalist housing product line. Similarly, Toyota has tentatively begun to explore the IH market as a line extension to its normal business.

This improved housing approach has facilitated the use of industrialized methods. For example, the highest precast levels in 1996 were located in Denmark (43\%), the Netherlands (40\%), Sweden and Germany (31\%) (Jaillon and Poon, 2009). In Asian counties other than Japan, such as Singapore, the IH approach was introduced in the early 1980s and several of the prefabrication systems were developed by local and overseas contractors (Wong and Yeh, 1985). In Malaysia, industrialized building systems (IBSs) have been established since the 1990s, with their very rapid growth in numbers providing a much needed solution to the considerable emphasis on building construction activities in the Malaysia Seventh Five-Year Plan (Badir et al., 2002).

In contrast, IH attempts in China are still emerging. The framework provided by the programme of the Trans-century Housing Industrialization Policy on China at the end of 1996 started the developing objectives and the overall guidelines for housing industrialization in China (Nie, 1999). With policy support from the Chinese government, a series of housing technology standards, including 'Coding Standards for Architectures', 'Technical Assessment for Residential Projects', 'Standards for Architectural Design' and 'Standard for Modular Coordination of Dwelling Houses' have been issued. A residential building system for IH has been created for cast-in-situ concrete and steel high rise residential structures. In addition, platform-based housing production has been adopted, wherein the proportion of factory production is increased and mechanization levels have greatly improved as a result. In this context, commercial concrete and pumped concrete have gained in popularity in residential projects in China's large and medium-sized cities, making IH a very promising option today.

The supply chain also plays a significant role in the $\mathrm{IH}$ process. In China, the production of residential construction materials has become a systematic manufacturing process. As a result, the variety and specifications, quality and performance of construction products and materials have improved significantly. A commercialized supply chain system has been 
established, which has provided the basic materials for $\mathrm{IH}$ in China. In meeting the demands for IH, two types of producers have emerged. One is the large housing developers, such as China Vanke, Hengda Real Estate Group and China Overseas. These have formed integrated multi-functional operation activities, including housing investment, product research and development, design, manufacture of components and parts, construction, sales and property management and related business services. Recently, another new type of housing producer has also emerged in the form of the Yaoda Building Material Co., Ltd., specializing in the design and production of prefabricated housing and environmental materials, and which is now considered to be one of China's leading suppliers of prefabricated homes. The Yaoda's motto is "One Day, One Home" - seemingly incongruous and understated message for the booming development stage of the current housing industry in China. This kind of IH approach appears largely limited to industrial prefabrication from firms producing the stylized suburban American Steel Villa product line.

In 2010, a new housing policy entitled 'Measures of Beijing on the Reward for IH Residential Projects' was issued, indicating that IH would be allocated to $3 \%$ of all construction work - proactively encouraging the rapid development of IH in future. In Shanghai, the 2010 World Exposition site, from which most of our analysis was derived, organized prefabricated housing units and related utility structures on the main arterials and on the perimeter of subdivided zones. China is regarded by many as a manufacturing powerhouse of the world with a huge market potential, relative low cost of productive resources such as land and labour, and an improving business environment (Zhao et al., 2006). The benefits offered by industrialized housing, the current housing needs of Chinese population and its highly competitive and advanced manufacturing capabilities seem to be just the three right ingredients needed to promote industrialized housing (Arif and Egbu, 2010). However, few previous studies have identified the bright and dark side of industrialized housing given the commonly accepted expectation: 'Industrialized housing for China seems to be an idea whose time has come'. Challenges may occur, especially as the housing industry has been orientated towards traditional construction approach for many decades. It is not easy to shift from 'traditional and on-site construction' to 'innovative and industrialized housing'. The following sections report on study of the two sides of IH by means of a questionnaire survey, interviews and case studies, aimed at providing answers to this question.

\section{RESEARCH METHODS}

The research data in this study was sought and collected using a combination of content analysis of the literature, questionnaire survey, structured face-to-face interviews with housing project managers and case-studies. Content analyses of the existing literature and research reports were adopted to examine the benefits and hindrances in implementing IH residential projects, while case-studies and interviews were employed to demonstrate the benefits and hindrances that occur during the application of the IH project development process.

\section{IDENTIFICATION OF BENEFITS AND HINDRANCES OF HOUSING INDUSTRIALIZATION}

The various benefits that have been introduced to housing industrialization practices are identified in several previous studies (e.g. Wong et al., 2003; Chen et al., 2010; Lessing et al., 2005), and which are comprehensively listed in Table 1. These are mainly focused on 
cost, productivity and quality and are typically concerned with the assessment of the benefits of prefabrication and off-site production (Blismas et al., 2006), while others have studied the design of industrialized architecture (Leila, 2010). What is noticeable, however, is the lack of investigation into the full benefits of $\mathrm{IH}$ (Jaillon and Poon, 2009).

The hindrances to IH have also been addressed in previous studies (Chiang et al, 2006; Tam et al., 2007; Jaillon et al., 2009), and are summarized in Table 2.

\section{DATA SURVEY}

A questionnaire survey was conducted in order to further understand the significance of the benefits of applying $\mathrm{IH}$ and the extent of the hindrances involved in its practical application. Questionnaire surveys are commonly adopted for collecting qualitative information of this kind from practice and, following Zhang et al. (2011) a mailed questionnaire was used as an effective method for obtaining the maximum possible response.

Table 1. Summary of typical benefits of housing industrialization

\begin{tabular}{lll}
\hline Code & Benefits & Key references \\
\hline $\mathrm{BHI}_{1}$ & Higher quality control & Ji and Xu, 2010 \\
$\mathrm{BHI}_{2}$ & Improved site safety & The Steel Construction Institute, \\
& & 2000 \\
$\mathrm{BHI}_{3}$ & Sustainable construction approach (e.g. elimination of waste) & The Steel Construction Institute, \\
& & 2000 \\
$\mathrm{BHI}_{4}$ & Reduction of construction time & Wong et al., 2003; Chen et al., 2010; \\
& & The Steel Construction Institute, \\
$\mathrm{BHI}_{5}$ & Cost saving & 2000 \\
$\mathrm{BHI}_{6}$ & Higher level of accuracy & Ji and Xu, 2010; Lessing et al., 2005 \\
$\mathrm{BHI}_{7}$ & Saving in site space & Tam et al., 2007 \\
& & The Steel Construction Institute, \\
$\mathrm{BHI}_{8}$ & Government support and encouragement & 2000 \\
$\mathrm{BHI}_{9}$ & Better organization in site management (Higher project & Tam et al., 2007 \\
& efficiency and labour productivity) & Ji and Xu, 2010; Chen et al., 2010 \\
$\mathrm{BHI}_{10}$ & Less affected by inclement weather & Chiang et al., 2006; Wong et al., \\
\end{tabular}

Table 2. Summary of typical hindrances for applying housing industrialization

\begin{tabular}{lll}
\hline Code & Hindrances & Key references \\
\hline $\mathrm{HHI}_{1}$ & Transportation problem & Chiang et al., 2006 \\
$\mathrm{HHI}_{2}$ & Monotone considerations & Vikan, 2008 \\
$\mathrm{HHI}_{3}$ & Skilled labours with higher wage & Swierk, 2005; Jaillon et al., 2009 \\
$\mathrm{HHI}_{4}$ & Limited site space for placing prefabricated building & Tam et al., 2007 \\
& components & Jaillon et al., 2009 \\
$\mathrm{HHI}_{5}$ & Lack of hoist equipment capacity & Swierk, 2005; Jaillon et al., 2009; \\
$\mathrm{HHI}_{6}$ & Higher initial cost & Tam et al., 2007 \\
$\mathrm{HHI}_{7}$ & Lack of on-site cast yard area & Jaillon et al., 2009 \\
$\mathrm{HHI}_{8}$ & Inflexibility of design & Swierk, 2005 \\
$\mathrm{HHI}_{9}$ & Lack of standard components' manufacturer & Jaillon et al., 2009 \\
\hline
\end{tabular}


The questionnaire comprised three parts: (a) questions relating to the respondents' individual and organizational backgrounds; (b) their opinions on the significance of benefits in applying IH, and (c) opinions on the hindrances in application of green elements. A Likert scale was used to represent respondents' opinions. This is commonly used for rating the relative significance of individual factors through expert opinions (e.g., Chan and Kumaraswamy, 1997; Zhang et al., 2011). For the relative significance of each benefit, a Grade ' 1 ' denotes the least significant and ' 5 ' the most significant. The respondents were also invited to judge the significance of each listed hindrance to the application of IH, with a grade "1" denoting the least significance, and " 5 " the most significant. A sample questionnaire is shown in the Appendix.

The survey was conducted among Chinese housing-related professionals with experience in IH development projects. Initially, a list of 75 housing related enterprises were identified from two databases (the Business Directory for the Chinese Housing Industry and the Registration enterprise list for Beijing International Housing Industrialization Forum at 2010). The reason of selecting the enterprises listed in the two databases as samples in the study is that these enterprises are classified as 'large scale 'and hence they have sufficiently strong financial resources necessary for the application of $\mathrm{IH}$ and are able to provide more relevant information. Then, invitation letters and e-mails were sent to the divisional professionals of these 75 organizations to participate in the survey. 43 organizations indicated their willingness to participate and the questionnaire was distributed by e-mail or post to the professionals of those organizations accepting the survey invitation. To increase the sample size, a 'snowball' sampling method was used. In other words, the professionals involved were invited to help distribute the questionnaire to their colleagues and business partners whom they knew to be experienced in $\mathrm{IH}$.
A total of 125 questionnaires were dispatched via both e-mail and conventional post in June 2010 and a follow-up reminder letter was sent to the respondents who had not returned the survey. Of 50 responses returned, three were not properly completed, leaving the remaining 47 (37.6\%) valid for analysis. Of the 47 valid responses, 9 were from the design professionals, 8 from engineers, 7 from real estate development, 7 from procurement and quantity surveyors, and 16 from the other professionals as shown in Table 3.

Table 3. Organization or department background for survey respondents

\begin{tabular}{lll}
\hline $\begin{array}{l}\text { Division of an } \\
\text { organization or } \\
\text { department }\end{array}$ & Response & Percentage \\
\hline Design & 9 & $19.1 \%$ \\
Engineering & 8 & $17.0 \%$ \\
Real estate development & 7 & $14.9 \%$ \\
Procurement and & 7 & $14.9 \%$ \\
quantity surveying & 5 & $10.6 \%$ \\
Property management & 4 & $8.5 \%$ \\
Legal affair & 3 & $6.4 \%$ \\
Sales and marketing & 2 & $4.3 \%$ \\
Agency & 2 & $4.3 \%$ \\
Property management & 47 & $100.0 \%$ \\
\hline Total & & \\
\hline
\end{tabular}

The demographic indicators considered were gender, age, working locations and working experience. Of the 47 respondents, $31(66 \%)$ are males and $16(34 \%)$ females, and with 13 (28\%) between 20-30 years of age, 15 (32\%) between 31-40 years and 19 (40\%) over 40 years old. The spatial distribution of the respondents' working locations covers the northern (36\%), eastern coastal (32\%), western (11\%) and southern (21\%) regions of China. As the housing industry in China mainland has only been in existence since the land use reform in 1987 (Chiu, 2001), the experience of the respondents is limited, with $12.8 \%$ being involved in the housing and construction industry for less than 5 years; $44.7 \%$ for 5 to 
10 years; $29.8 \%$ for 11 to 15 years' and only the remaining $12.8 \%$ with more than 15 years' experience.

As for housing industrialization experience, half of the respondents possessed related experience, with 23 respondents having no IH experience, 20 having participated in one $\mathrm{IH}$ project, and 3 in two IH projects and the remaining 1 respondent in one $\mathrm{IH}$ project.

\section{SURVEY RESULTS}

The relative significance of each of the 10 benefits was derived on the basis of the mean values of responses, as summarized in Table 4. This indicates that the most effective benefit of applying $\mathrm{IH}$ is the sustainable construction approach, with the highest mean value rating of 4.787. This is followed by higher level of accuracy (4.745) and higher quality control (4.617). Saving in site space and better organization in site management are ranked as fourth and fifth respectively.

As is well documented in the literature (Jaillon and Poon, 2009), the IH approach can be a major driver in reducing the impact of construction activities on the environment. This is echoed in the survey result of the top benefit for IH being the sustainable construction approach. The potential environmental benefits of IH are numerous, such as the reduction of construction waste on site, the reduction of air, dust and noise pollution during on-site construction activities, the conservation of construction material, etc., and the survey result supports this in the context of prefabrication. The case studies recounted later provide more information demonstrating the level of environmental benefits that can be achieved by IH.

The relative significance of each of the 9 listed hindrances was identified on the basis of mean values of individual responses (Table 5). It appears that the higher initial cost provides the largest hindrance, with the highest mean value rating of 4.149 . This is followed by skilled labours with higher wage (3.979) and lack of hoist equipment capacity (3.660). Inflexibility of design and monotone considerations are ranked as fourth and fifth respectively. It is interesting to note that the higher cost is IH is a priority according to industry opinion. Compared with the traditional housing projects, the initial cost can higher for a number of reasons, such as the transportation cost of prefabricated components; higher labour costs and more expensive precast components for installation. This is also consistent with the findings of the previous study by Jaillon and Poon (2009), indicating that the project costs are higher with prefabrication than conventional construction.

Table 4. The relative significance of benefits in IH

\begin{tabular}{|c|c|c|c|c|c|c|}
\hline Code & Statement (Advantage) & Number & Mean & Minimum & Maximum & Rank \\
\hline $\mathrm{BHI}_{3}$ & $\begin{array}{l}\text { Sustainable construction approach } \\
\text { (e.g. elimination of waste) }\end{array}$ & 47 & 4.787 & 3 & 5 & 1 \\
\hline $\mathrm{BHI}_{6}$ & Higher level of accuracy & 47 & 4.745 & 3 & 5 & 2 \\
\hline $\mathrm{BHI}_{1}$ & Higher quality control & 47 & 4.617 & 3 & 5 & 3 \\
\hline $\mathrm{BHI}_{7}$ & Saving in site space & 47 & 4.447 & 3 & 5 & 4 \\
\hline $\mathrm{BHI}_{9}$ & Better organization in site management & 47 & 4.362 & 3 & 5 & 5 \\
\hline $\mathrm{BHI}_{2}$ & Improved site safety & 47 & 4.340 & 3 & 5 & 6 \\
\hline $\mathrm{BHI}_{4}$ & Reduction of construction time & 47 & 4.085 & 3 & 5 & 7 \\
\hline $\mathrm{BHI}_{10}^{*}$ & Less affected be inclement weather & 47 & 3.149 & 2 & 5 & 8 \\
\hline $\mathrm{BHI}_{5}$ & Cost saving & 47 & 3.021 & 2 & 4 & 9 \\
\hline $\mathrm{BHI}_{8}$ & Government support and encouragement & 47 & 2.957 & 2 & 4 & 10 \\
\hline
\end{tabular}


Table 5. The relative significance of hindrances in applying IH

\begin{tabular}{lllllll}
\hline Code & Hindrances & Number & Mean & Minimum & Maximum & Rank \\
\hline $\mathrm{HHI}_{6}$ & Higher initial cost & 47 & 4.149 & 2 & 5 & 1 \\
$\mathrm{HHI}_{3}$ & Skilled labourers with higher wage & 47 & 3.979 & 2 & 5 & 2 \\
$\mathrm{HHI}_{5}$ & Lack of hoist equipment capacity & 47 & 3.660 & 2 & 4 & 3 \\
$\mathrm{HHI}_{8}$ & Inflexibility of design & 47 & 3.489 & 2 & 4 & 4 \\
$\mathrm{HHI}_{2}$ & Monotone considerations & 47 & 3.128 & 2 & 4 & 5 \\
$\mathrm{HHI}_{1}$ & Transportation problem & 47 & 3.043 & 2 & 4 & 6 \\
$\mathrm{HHI}_{7}$ & Lack of onsite cast yard area & 47 & 2.979 & 2 & 4 & 7 \\
$\mathrm{HHI}_{4}$ & Limited site space for placing & 47 & 2.809 & 2 & 4 & 8 \\
& prefabricated building components & & & & & \\
$\mathrm{HHI}_{9}$ & Lack of standard components' & 47 & 2.574 & 2 & 4 & 9 \\
& manufacturer & & & & & \\
\hline
\end{tabular}

Table 6. Profiles of the case study IH projects

\begin{tabular}{|c|c|c|c|}
\hline Project type & Project description & $\begin{array}{l}\text { Housing } \\
\text { developer }\end{array}$ & $\begin{array}{l}\text { Property } \\
\text { location }\end{array}$ \\
\hline $\begin{array}{l}\text { Project I: } \\
\text { Project for } \\
\text { commercial } \\
\text { housing use }\end{array}$ & $\begin{array}{l}\text { Xinlicheng uptown, the project is an } 18 \text { stories residential } \\
\text { building with a total construction area of } 238,900 \mathrm{~m}^{2} \text {, } \\
\text { started from July } 15,2007 \text {, and was finished on July, } 2010 \text {. }\end{array}$ & Vanke & Shanghai \\
\hline $\begin{array}{l}\text { Project II: } \\
\text { Project for public } \\
\text { rental housing use }\end{array}$ & $\begin{array}{l}\text { This project belongs to the affordable housing type with a } \\
\text { total construction area of } 210,000 \mathrm{~m}^{2} \text {, started from August, } \\
2010 \text {, the first phase of project was completed on June, } \\
2011 \text { and the whole project will be finished on July, } 2012 \text {. }\end{array}$ & Vanke & Shenzhen \\
\hline $\begin{array}{l}\text { Project III: } \\
\text { Project for } \\
\text { Shanghai World } \\
\text { Expo use }\end{array}$ & $\begin{array}{l}\text { This project is a } 6 \text { story-exhibition building with a total } \\
\text { construction area of } 1900 \mathrm{~m}^{2} \text {, completed within one day's } \\
\text { time in } 2010 \text {. }\end{array}$ & $\begin{array}{l}\text { Broad } \\
\text { sustainable } \\
\text { building } \\
\text { Company } \\
\end{array}$ & Shanghai \\
\hline
\end{tabular}

\section{CASE STUDY}

Case studies can be used for explorative, descriptive, explanatory or illustrative research (Yin, 2007). Yin (2007) also argues that interviews are the most important source of information in case studies and interviews were also conducted for the collection of data in this study. Though a frequent criticism of the case study methodology is that its dependence on a single case renders it incapable of providing a generalizable conclusion, case studies are considered to be acceptable by many researches, provided they meet the established objectives (Tellis, 1997; Zhang et al., 2011). For example, a case study is a suitable strategy for carry- ing out research through empirical investigation of a contemporary phenomenon within its real life context using multiple sources of evidence. A comprehensive case study allows the researcher to pursue a progressive strategy, from the exploration of a proposition to more a focused examination of trials. Given the nature of the research rationale in this paper, the case study strategy is clearly appropriate.

In case studies, interviews are typically not as strictly structured as in survey studies and often involve semi-structured interviews. In this section, IH practices are illustrated and described via three typical cases (see Figure 1). Table 6 briefly summarises the profiles of the three cases (namely, Project I, Project II, and 
Project III) selected for the study. In the case studies, the benefits and hindrances for applying IH are investigated and compared in detail.

\section{FINDINGS AND DISCUSSION}

This section analyses and discusses the major findings revealed by the case study. First, the benefits and hindrances in applying IH from the three case studies is identified and summarised through several face to face interview discussions. Finally, the major implications of applying $\mathrm{IH}$ in the housing projects in China are summarised.

The benefits and hindrances involved in applying IH in various stages of housing projects

An analysis was conducted of the comparative benefits and hindrances of $\mathrm{IH}$ practices at various stages of projects among the three cases, and the results are provided in Table 7 . The results were generated by using on-site observations and discussions with site staffs involved in the three cases.

Consistent with the findings of the questionnaire survey, the three case studies involved low carbon methods of construction, contributing to sustainable development $\left(\mathrm{BHI}_{3}\right)$ being one of the main benefits of IH implementation, particularly in China. According to interview discussions with the site manager in Case I, the main benefits during the installation and site restoration stage were derived from the shorter construction period, which helps weaken the project's impact on the local environment. By using IH, the total saving of the timber shuttering was $87 \%$ and with water saving as much as $70 \%$ (20\% of the energy saving is achieved per square meter) in the building construction process. The waste was also drastically reduced (30\%) because of the efficient factory production and assembly involved, and the reduced damage of construction materials on-site. Foundation excavation was minimized and there were fewer potentially wasteful site activities.

In Case II, several benefits were identified in the process of construction. The developer is Vanke China which, in order to build the largest public affordable housing project in Shenzhen, made a determined effort to make the project succeed and the construction process benefitted in many ways as a result. For one example, Vanke has developed many small dwelling-size projects previously, which has made them more professional in running affordable public housing.

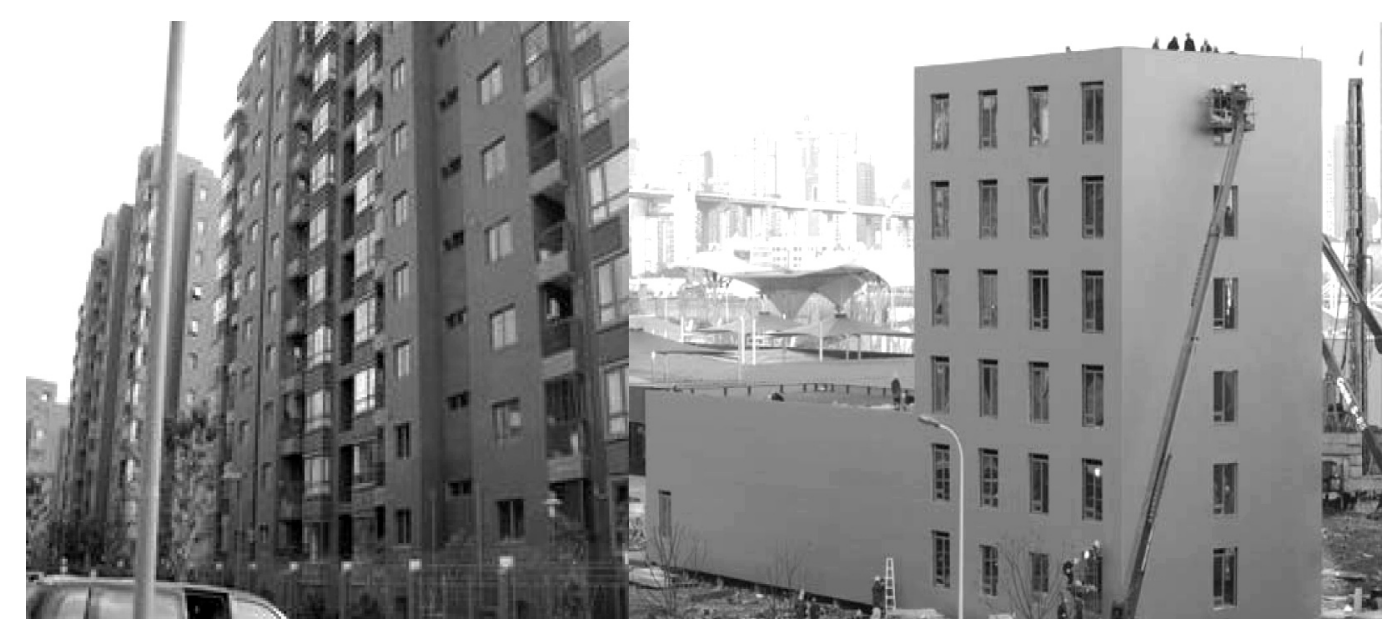

Figure 1. Two of the housing projects selected for case study 
Table 7. The benefits and encountered hindrances in various project stages of the three cases

\begin{tabular}{|c|c|c|}
\hline & Benefits (refer to Table 4) & Hindrances encountered (refer to Table 5) \\
\hline $\begin{array}{l}\text { Planning and } \\
\text { design }\end{array}$ & $\begin{array}{l}\text { Case I: } \\
\mathrm{BHI}_{1} \\
\text { Case II: } \\
\text { BHI }_{5} ; \mathrm{BHI}_{8} \\
\text { Case III: } \\
\mathrm{BHI}_{6} ; \mathrm{BHI}_{8}\end{array}$ & $\begin{array}{l}\text { Case I: } \\
\mathrm{HHI}_{6} ; \mathrm{HHI}_{1} ; \mathrm{HHI}_{2} ; \mathrm{HHI}_{8} \\
\text { Case II: } \\
\mathrm{HHI}_{6} ; \mathrm{HHI}_{8} \\
\frac{\text { Case III: }}{\mathrm{HHI}_{2}}\end{array}$ \\
\hline $\begin{array}{l}\text { Permit and } \\
\text { approval }\end{array}$ & $\begin{array}{l}\text { Case I: } \\
\mathrm{BHI}_{1} ; \mathrm{BHI}_{5} \\
\text { Case II: } \\
\text { BHI }_{1} ; \mathrm{BHI}_{8} ; \mathrm{BHI}_{5} \\
\text { Case III: } \\
\mathrm{BHI}_{8} ; \mathrm{BHI}_{5}\end{array}$ & $\begin{array}{l}\text { Case I: } \\
\mathrm{HHI}_{2} ; \mathrm{HHI}_{8} ; \mathrm{HHI}_{6} \\
\text { Case II: } \\
\mathrm{HHI}_{6} ; \mathrm{HHI}_{2} \\
\text { Case III: } \\
\mathrm{HHI}_{2} ; \mathrm{HHI}_{8}\end{array}$ \\
\hline $\begin{array}{l}\text { Site } \\
\text { development and } \\
\text { prefabrication } \\
\text { building } \\
\text { components at } \\
\text { plant }\end{array}$ & $\begin{array}{l}\text { Case I: } \\
\mathrm{BHI}_{6} ; \mathrm{BHI}_{1} ; \mathrm{BHI}_{2} ; \mathrm{BHI}_{3} \\
\text { Case II: } \\
\mathrm{BHI}_{6} ; \mathrm{BHI}_{10} ; \mathrm{BHI}_{2} \\
\text { Case III: } \\
\mathrm{BHI}_{3} ; \mathrm{BHI}_{1} ; \mathrm{BHI}_{6}\end{array}$ & $\begin{array}{l}\text { Case I: } \\
\mathrm{HHI}_{9} ; \mathrm{HHI}_{6} ; \mathrm{HHI}_{1} \\
\text { Case II: } \\
\mathrm{HHI}_{6} ; \mathrm{HHI}_{9} ; \mathrm{HHI}_{5} ; \mathrm{HHI}_{4} \\
\text { Case III: } \\
\mathrm{HHI}_{4} ; \mathrm{HHI}_{6} ; \mathrm{HHI}_{9}\end{array}$ \\
\hline $\begin{array}{l}\text { Install and site } \\
\text { restoration }\end{array}$ & $\begin{array}{l}\text { Case I: } \\
\mathrm{BHI}_{3} ; \mathbf{B H I}_{6} ; \mathrm{BHI}_{4} ; \mathrm{BHI}_{7} ; \mathrm{BHI}_{9} \\
\text { Case II: } \\
\mathrm{BHI}_{2} ; \mathbf{B H I}_{3} ; \mathrm{BHI}_{6} ; \mathrm{BHI}_{4} \\
\text { Case III: } \\
\mathrm{BHI}_{4} ; \mathrm{BHI}_{5} ; \mathbf{B H I}_{6} ; \mathbf{B H I}_{3}\end{array}$ & $\begin{array}{l}\text { Case I: } \\
\mathrm{HHI}_{9} ; \mathrm{HHI}_{1} ; \mathrm{HHI}_{3} \\
\text { Case II: } \\
\mathrm{HHI}_{9} ; \mathrm{HHI}_{6} ; \mathrm{HHI}_{1} ; \mathrm{HHI}_{7} \\
\text { Case III: } \\
\mathrm{HHI}_{7} ; \mathrm{HHI}_{9}\end{array}$ \\
\hline $\begin{array}{l}\text { Property } \\
\text { management and } \\
\text { feedback }\end{array}$ & $\begin{array}{l}\text { Case I: } \\
\mathrm{BHI}_{3} ; \mathrm{BHI}_{7} \\
\text { Case II: } \\
\mathrm{BHI}_{3} ; \mathrm{BHI}_{2} \\
\text { Case III: } \\
\mathrm{BHI}_{5}\end{array}$ & $\begin{array}{l}\text { Case I: } \\
\mathrm{HHI}_{3} ; \mathrm{HHI}_{6} \\
\text { Case II: } \\
\mathrm{HHI}_{8} \\
\frac{\text { Case III: }}{\mathrm{HHI}_{3}}\end{array}$ \\
\hline
\end{tabular}

For another, affordable housing projects are relatively more suitable for IH since they tend to be more standardized. According to interview discussions on-site with key project informants, government support for the project played a major role in the planning and design stage. Also the IH approach brought about higher quality control and cost savings during the permit and approval stage due to the purchase cost for the high quality housing design being relatively low compared with traditional housing. In fact, IH has brought about much quality improvement by controlling the housing product quality to an accuracy of within a millimetre. In 2009, the Vanke Gold Ya-Ju residential project in Shanghai experienced a serious quality crisis, which severely affected the brand reputation (Shanghai Estate market weekly, 2009). The Gold Ya-Ju project was developed by using the traditional construction approach, which inevitably created many problems, such as uneven water and cross-floor water penetration. In this case, IH provides a better solution. As voiced by Weijun Zhou, Executive Vice President of Vanke Group, the implementation of IH has improved the accuracy of the wall building dimensions from centimetres to millimetres, which helps to avoid many quality problems (i.e., sound insulation and water leakage) (Yang et al., 2011).

In the site development and prefabrication of building components production stage, the 
foundation formwork was cut-to-size and bent to shape at the plant ready for installation on site - a sustainable construction approach that produces very little waste and obtains a clean and greener construction site. For the install and site restoration stage, a high level of accuracy was found in the installation process. The total construction time was also reduced overall.

As for the Case III, two typical benefits were highlighted in the interviews:

- Speed of construction in achieving a tight programme to meet the start of the Shanghai World Expo;

- A sustainable construction approach.

The project was completed within one working day. The site installation of the modular units was a rapid and quiet operation that could be done 'just in time', with no requirement for site storage or additional noisy equipment. Apart from the rapid construction speed and low carbon method of construction, the delivery of a large number of relatively small amounts of site materials was greatly reduced. It was revealed by the project manager of the Case III project that construction materials were used more efficiently and a greater accuracy of installation and production produced in the plant provided a considerable economy of use.

Of course, as every coin has two sides, the three case studies highlighted several existing hindrances in applying the IH approach. Among them, the higher initial cost and lack of standard components were nominated as the most frequent in discussions with key informant - echoing the results of the questionnaire survey. However, the lack of standard component manufacturers conflicts with the survey results, which ranked this factor in only $9^{\text {th }}$ place. The final section that follows addresses these points in more detail.

\section{High initial costs}

The concern over initial costs remains the primary barrier to IH. Precast components in- volving steel formwork, for example, have a production cost that is much higher than wood. In USA, home buyers can save labour costs by assembling the home themselves. However, the labour cost in China is much less than most developed countries and according to interview discussions with the project managers in case I, the production cost for $\mathrm{IH}$ is $350-500 \mathrm{RMB}$ per square meter more than traditional housing in China. Vanke's views are similar, as they state that developing 5,000,000 square meters per year will cost an extra 200,000,000 RMB if IH is used. It is clear, therefore, that it is unlikely that any cost benefits will be enjoyed by the use of IH in China. However, Vanke has dedicated itself to the pursuit of $\mathrm{IH}$ in China. As is maintained by Mao Daqing, Vice-president of China Vanke Co Ltd interviewed by China Daily, "Selling only decorated, environmentfriendly homes built in a highly industrialized way is Vanke's strategic focus for 2010". All these efforts, Mao said, are aimed at reducing the energy consumed in the building process and improving operational efficiency, which are considered to be the company's competitive strengths in comparison with its rivals (Mao, 2010). In this regard, it is considered that real estate developers with a strategic vision such as Vanke will have their own incentives to implement IH by risking the possibility of higher development costs.

Lack of standard components manufacturers

It is currently very difficult to have any large scale IH projects in China since there are very few off-site construction component manufacturers. Most of the construction materials and joints are not standardized, making IH hard to design as component manufacturers cannot match the assembly process on site. In this respect, it is rather difficult for contractors on site to guarantee quality, mechanization and standardization. There is also a lack of local R\&D, support services, technologies and testing labs for IH in China. For example, the production of reinforcing steel bars in Japan 
is always in the form of screw plugs, which are easier to install on site, while there are no equivalent manufacturing facilities in China. Taking the Vanke organisation as an example, most of their IH projects in Beijing, Shanghai and Shenzhen have used large nationalized infrastructure precast components. However, most of the manufacturers of these components cannot provide the systematic, customized, mechanized and standardized manufacturing process needed for IH generally.

\section{RECOMMENDATIONS: THE WAY FORWARD}

The previous sections have identified the bright and dark sides of $\mathrm{IH}$ in presenting a general profile of the application of $\mathrm{IH}$ in China. In considering the drawbacks, both the survey and follow up case studies indicate two interdependent major hurdles preventing the increased use of $\mathrm{IH}$ in China at present. The first is that $\mathrm{IH}$ is not yet cost effective in comparison with traditional housing. In order to ameliorate the high initial cost of $\mathrm{IH}$, it is suggested that land for IH projects is made available. As is presented in Case Study II, the IH project was approved by the authorities to acquire land quickly and cheaply for publichousing purposes. In view of this, it may be beneficial to have additional legislation from central and local government regulating compulsory land acquisition for IH projects in order to improve the development of $\mathrm{IH}$ in the future.

Secondly, there are insufficient manufacturers of prefabricated construction components as yet for IH to be viable on any scale throughout the country. In view of this, the most obvious source of improvement is likely to be further government support and investment, either in the form of large state-owned manufacturing enterprises (as already exist in Russia for example) or substantial subsidies to encourage greater private sector investment.
In China, the present building regulations appear to be in need of more enforcement to safeguard the public interest. To maintain safety in the built environment it would seem wise to encourage prefabricated construction to fullscale industrialization since quality control in $\mathrm{IH}$ is much easier than in traditional construction activities. However, in a country such as China, this is a radical strategy and unlikely to be made without a lengthy period of deliberation and trials.

\section{CONCLUSION}

Industrialization approach is not new in developed countries in Europe and the USA, while it is a brand new concept in both the housing and construction sectors in many developing counties such as China. Recent developments in the Chinese housing industry display many similarities with industries where platform-based approaches have successfully been adopted and the several government initiatives have been made to date in support of this. This paper examines the prospects for a greater degree of mechanisation in China's construction industry with particular focus on the industrialisation of housing projects through the increased use of off-site prefabrication of components. The results of a survey are presented that substantial benefits can be produced by IH, amongst which is the impressive contribution to environmental protection.

Of course, it should also be added that this paper only offers a narrow view of $\mathrm{IH}$ from an economic (and to some extent environmental) perspective. Nothing has been said concerning the design and habitation aspect of IH. In this respect, what has happened in the past (in the 1960s UK for example) is not encouraging. There are many counter examples though, which suggest that the problem is less caused by IH itself but by insensitive design and planning decisions in an effort to exploit the potential of mass production beyond the mere value 
for money issues to the point of being 'dirty and cheap'. The great hope is that, if IH does eventually become extensively used in China, it will not fall into the same trap. As with the environment in general, our heritage is our greatest concern and this applies equally to our buildings and their occupants.

\section{REFERENCES}

Arif, M. and Egbu, C. (2010) Making a case for offsite construction in China, Engineering, Construction and Architectural Management, 17(6), pp. 536-548.

http://dx.doi.org/10.1108/09699981011090170

Austin, S., Baldwin, A., Li, B. and Waskett, P. (2000) Analytical design planning technique (ADePT): a dependence structure matrix tool to schedule the building design process, Construction Management and Economics, 18(2), pp. 173-182. http://dx.doi.org/10.1080/014461900370807

Badir, Y. F., Kadir, M. R. A. and Hashim, A. H. (2002) Industrialized building systems construction in Malaysia, Journal of Architectural Engineering-ASCE, 8(1), pp. 19-23. http://dx.doi. org/10.1061/(ASCE)1076-0431(2002)8:1(19)

Barlow, J. and Ozaki, R. (2005) Building mass customized housing through innovation in the production system: lessons from Japan, Environment and Planning A, 37(1), pp. 9-20. http://dx.doi.org/10.1068/a3579

Barlow, J., Childerhouse, P., Gann, D., Hong-Minh, S., Naim, M. and Ozaki, R. (2003) Choice and delivery in housebuilding: lessons from Japan for UK housebuilders, Building Research and Information, 31(2), pp. 134-145.

http://dx.doi.org/10.1080/09613210302003

Blismas, N., Pasquire, C. and Gibb, A. (2006) Benefit evaluation for off-site production in construction, Construction Management and Economics, 24(2), pp. 121-130. http://dx.doi.org/10.1080/01446190500184444

Chen, Y., Okudan, G. E. and Riley, D. R. (2010) Sustainable performance criteria for construction method selection in concrete buildings, $\mathrm{Au}$ tomation in Construction, 19(2), pp. 235-244. http://dx.doi.org/10.1016/j.autcon.2009.10.004

Cheng, M. Y. and Tsai, M. H. (2003) Reengineering of construction management process, Jour- nal of Construction Engineering and Management-ASCE, 129(1), pp. 105-114. http://dx.doi. org/10.1061/(ASCE)0733-9364(2003)129:1(105)

Chiang, Y. H., Chan, E. H. W. and Lok, L. K. L. (2006) Prefabrication and barriers to entry-a case study of public housing and institutional buildings in Hong Kong, Habitat International, 30(3), pp. 482-499. http://dx.doi.org/10.1016/j. habitatint.2004.12.004

Chiu, R. L. H. (2001) Commodification of housing with Chinese characteristics, Review of Policy Research, 18(1), pp. 75-95. http://dx.doi. org/10.1111/j.1541-1338.2001.tb00968.x

Dawood, N. (1996) An integrated intelligent planning approach for modular construction. In: Proceedings of $3^{r d}$ congress on computer in civil engineering, Anaheim, USA.

Gann, D. M. (1996) Construction as a manufacturing process? Similarities and differences between industrialized housing and car production in Japan, Construction Management and Economics, 14(5), pp. 437-450.

http://dx.doi.org/10.1080/014461996373304

Gibb, A. (2001) Standardization and pre-assemblydistinguishing myth from reality using case study research, Construction Management and Economics, 19(3), pp. 307-315. http://dx.doi. org/10.1080/01446190010020435

Gibb, A. and Isack, F. (2003) Re-engineering through pre-assembly: client expectations and drivers, Building Research \& Information, 31(2), pp. 146-160.

http://dx.doi.org/10.1080/09613210302000

Goodier, C. and Gibb, A. (2007) Future opportunities for offsite in the UK, Construction Management and Economics, 25(6), pp. 585-595.

http://dx.doi.org/10.1080/01446190601071821

Green, S. D., Fernie, S. and Weller, S. (2005) Making sense of supply chain management: a comparative study of aerospace and construction, Construction Management and Economics, 23(6), pp. 579-593. http://dx.doi.org/10.1080/01446190500126882

Halman, J. I. M., Voordijk, J. T. and Reymen, I. M. M. J. (2008) Modular approaches in Dutch house building: an exploratory survey, Housing Studies, 23(5), pp. 781-799. http://dx.doi.org/10.1080/02673030802293208

Howell, G. A. and Koskela, L. J. (2000) Reforming project management: the role of lean construction. In: $8^{\text {th }}$ annual conference of the Interna- 
tional Group for Lean Construction, 17th - 19th July 2000, Brighton, UK.

Jaillon, L. and Poon, C. S. (2009) The evolution of prefabricated residential building systems in Hong Kong: a review of the public and the private sector, Automation in Construction, 18(3), pp. 239-248.

http://dx.doi.org/10.1016/j.autcon.2008.09.002

Jaillon, L., Poon, C. S. and Chiang, Y. H. (2009) Quantifying the waste reduction potential of using prefabrication in building construction in Hong Kong, Waste Management, 29(1), pp. 309-320.

http://dx.doi.org/10.1016/j.wasman.2008.02.015

Ji, Y. B. and Xu, B. (2010) The analysis on the core competitiveness of construction enterprises based on the industrial housing construction. In: The $5^{\text {th }}$ international conference on computer sciences and convergence information technology (ICCIT), Nov. 30 2010-Dec. 22010. Available at: http://ieeexplore.ieee.org/stamp/ stamp.jsp?arnumber $=05711156$

Kagioglou, M., Cooper, R., Aouad, G. and Sexton, M. (2000) Rethinking construction: the generic design and construction process protocol, Engineering, Construction and Architectural Management, 7(2), pp. 141-153.

http://dx.doi.org/10.1108/eb021139

Leila, M. (2010) Industrialized construction systems in sustainable housing. In: $22^{\text {nd }}$ international housing research conference on urban dynamics \& housing change - crossing into the 2nd decade of the 3rd millennium, ENHR 2010, 4-7 July, Istanbul. Available at: http://enhr2010.com/ fileadmin/templates/ENHR2010_papers_web/ papers_web/WS11/WS11_82_Mirsaeedie.pdf

Lessing, J., Stehn, L. and Ekholm, A. (2005) Industrialised housing - definition and categorization of the concept, In: Proceedings of the in the $13^{\text {th }}$ annual conference in the International Group for Lean Construction.

Lin, T. Y. and Stotesbury, S. D. (1970) Recent technological developments in industrialized production of housing. In: Proceedings of the $\mathrm{Na}$ tional Academy of Sciences of the United States of America, 67(2), pp. 861-876.

http://dx.doi.org/10.1073/pnas.67.2.861

Liu, Z. Y. and Ying, H. Q. (2009) Prefabrication construction in residential building of Vanke real estate company China. In: International conference on management and service science, 20-22 Sept. 2009, pp. 1-4.
London, K. and Kenley, R. (2001) An industrial organizations economic supply chain approach for the construction industry: a review, Construction Management and Economics, 19(8), pp. 777-788.

http://dx.doi.org/10.1080/01446190110081699

Mao, D. Q. (2010) Real estate developer capitalizes on growth, China Daily. Available at: http://english.peopledaily.com. cn/90001/90778/90860/6905608.html

Mokhtar, S. N. and Mahmood, N. Z. (2008) Approach in construction industry: a study on prefabrication method as a tool for waste minimization. In: International conference on environmental research and technology (ICERT 2008), Malaysia.

Naim, M. and Barlow, J. (2003) An innovative supply chain strategy for customized housing, Construction Management and Economics, 21(6), pp. 593-602.

http://dx.doi.org/10.1080/0144619032000134129

Nie, M. S. (1999) Current situation and development of the housing construction in China, Research report for Ministry of Construction. Available at: http://www.housingauthority.gov.hk/eng/ events/conf/conferen/pdf/eniems.pdf

Richard, R. B. (2004) Industrialized building systems for housing the 'palette' of options, International Journal for Housing Science and Its Applications, 28(1), pp. 1-7.

Schmitt, T. and Faaland, B. (2004) Scheduling recurrent construction, Naval Research Logistics, 51(8), pp. 1102-1128.

http://dx.doi.org/10.1002/nav.20043

Shanghai Estate market weekly (2009) The water leakage problem of Vanke Gold Ya-Ju in Shanghai. Available at: http://jinseyazhuwk. soufun.com/bbs/1210430542 1 6141/70397609 _70397609.htm

Swierk, E. (2005) Prefabricated residential construction, Project report for ARCH 030. Available at: http://www-cs-students.stanford.edu/ eswierk/ misc/arch030/prefab-report.pdf

Tam, C. M., Tam, V. W. Y., Chan, J. K. W. and Ng, W. C. Y. (2005) Use of prefabrication to minimise construction waste - a case study approach, International Journal of Construction Management, 5(1), pp. 91-101.

Tam, V. W. Y., Shen, L. Y. and Tam, C. M. (2007) Assessing the levels of material wastage affected by sub-contracting relationships and 
projects types with their correlations, Building and Environment, 42(3), pp. 1471-1477. http://dx.doi.org/10.1016/j.buildenv.2005.12.023

Tam, V. W. Y., Tam, C. M., Zeng, S. X. and Ng, W. C. Y. (2007) Towards adoption of prefabrication in construction, Building and Environment, 42(10), pp. 3642-3654.

http://dx.doi.org/10.1016/j.buildenv.2006.10.003

Tellis, W. (1997) "Introduction to case study", the Qualitative Report, 3(2). Available at: http:// www.nova.edu/ssss/QR/QR3-3/tellis2.html

The Steel Construction Institute (2000) Value and benefits assessment of modular construction, Research report published for the 'Modular Matters' conference, London, September, 2000. Available at: http://www.designforhomes.org/ media/pdfs/ModularSteel.pdf

Vikan, H. (2008) Means of improving concrete construction productivity -State of the art. Research report for SINTEF Building and Infrastructure. Available at: http://www.sintef.no/ upload/Byggforsk/Publikasjoner/coin-no8.pdf

Voordijk, H., Meijboom, B. and de Haan, J. (2006) Modularity in supply chains: a multiple case study in the construction industry, International Journal of Operations \& Production Management, 26(6), pp. 600-618.

http://dx.doi.org/10.1108/01443570610666966

Winch, G. (2003) Models of manufacturing and the construction process: the genesis of reengineer- ing construction, Building Research \& Information, 31(2), pp. 107-118.

http://dx.doi.org/10.1080/09613210301995

Wong, A. K. and Yeh, S. H. K. (1985) Housing a nation, 25 years of public housing in Singapore, Housing and Development Board, Singapore, pp. 175-177.

Wong, R., Hao, J. L. and Ho, C. M. F. (2003) Prefabricated building construction systems adopted in Hong Kong. In: Proceedings of the international association for housing science on word congress of housing: process and product, Montreal, Canada.

Yang, L. Q., Ye, S. L. and Xu, X. C. (2011) Siege of government regulation: Boao real estate forum, Chinese EMBA Entrepreneur Net. Available at: http://www.embasoul.com/news\%5C201108 18\%5C634492394122300000_1.shtml

Yin, R. K. (2007) Case study research: design and methods. London: Sage Publications.

Zhang, X. L., Platten, A. and Shen, L. Y. (2011) Green property development practice in China: costs and barriers, Building and Environment, 46(11), pp. 2153-2160. http://dx.doi.org/10.1016/j.buildenv.2011.04.031

Zhao, X., Sum, C. C., Qi, Y., Zhang, H. and Lee, T. S. (2006) A taxonomy of manufacturing strategies in China, Journal of Operations Management, 24(5), pp. 621-636. http://dx.doi.org/10.1016/j.jom.2005.07.003 